\title{
DIFFERENCE IN PATHO-ANATOMY AND ITS INFLUENCE ON THE TECHNIQUE OF PERFORMING LAPAROSCOPIC CHOLECYSTECTOMY
}

\author{
Pratap Sanyal ${ }^{1}$, Ajay Saha ${ }^{2}$, Goutam Chakraborty ${ }^{3}$ \\ ${ }^{1}$ Assistant Professor, Department of Surgery, Tripura Medical College. \\ ${ }^{2}$ Associate Professor, Department of Surgery, Tripura Medical College. \\ ${ }^{3}$ Assistant Professor, Department of Surgery, Tripura Medical College.
}

\section{ABSTRACT}

AIM

To document the differences in pathoanatomy of the gallstone disease between Tribals and Non-Tribals of Tripura.

\section{MATERIALS AND METHOD}

This retrospective study includes 719 cases who underwent laparoscopic cholecystectomy during the period February 2012 to January 2015 of which 163 were Tribals and remaining 556 were non-Tribals. History and symptoms of presentation were noted in both the groups and duration to first consultation also noted in both the groups.

\section{RESULT}

It has been observed that the disease is more prevalent in non-Tribals than Tribals. While performing laparoscopic cholecystectomy, it has been noted that adhesions of Gall bladder are more common in non-Tribals; $15.95 \%$ of Tribals had adhesions with omentum and adjacent viscera in contrast to $23.9 \%$ in non-Tribals; $19.2 \%$ of adhesions were thick in Tribals, whereas $30.82 \%$ were thick in non-Tribals; $15.38 \%$ adhesions were tough in Tribals in comparison to $28.57 \%$ amongst non-Tribals.

\section{CONCLUSION}

Laparoscopic cholecystectomy is comparatively easier in Tribals than non-Tribals due to difference in pathoanatomy including relatively redundant mesentery of Gall bladder making the dissection easier.

\section{KEYWORDS}

Cholecystectomy, Laparoscopic Cholecystectomy.

HOW TO CITE THIS ARTICLE: Sanyal P, Saha A, Chakraborty G. "Difference in patho-anatomy and its influence on the technique of performing laparoscopic cholecystectomy." Journal of Evolution of Medical and Dental Sciences 2015; Vol. 4, Issue 104, December 28; Page: 16939-16940, DOI: $10.14260 /$ jemds/2015/2553

\section{INTRODUCTION}

Gall stone is a highly prevalent disease in Tripura and it depends on many factors, the main being age and gender of the patient. Of the other factors, the ethnic background has also an influence. ${ }^{1}$ Gall stones are very common among Mediterranean races and highest among Indians of New Mexico. Since the pioneering work of Phillipe Mouret in Lyon, France, in 1987. Laparoscopic cholecystectomy is the most effective surgical technique for management of symptomatic gall stone disease. ${ }^{2}$ and it comprises the major bulk of operations done by general surgeons in our state. This study aims to document the differences in pathoanatomy of the gall stone disease between Tribals and non-Tribals of Tripura.

\section{METHOD}

We are performing laparoscopic cholecystectomy since 1997. We noticed differences in the pathoanatomy of gall bladder in Tribal and non-Tribal population of Tripura and decided to document it from February 2012 to January 2015.

Financial or Other, Competing Interest: None.

Submission 15-12-2015, Peer Review 16-12-2015,

Acceptance 24-12-2015, Published 28-12-2015.

Corresponding Author:

Dr. Ajay Saha

Associate Professor

Department of Surgery,

Tripura Medical College,

Hapania, Agartala-14.

E-mail: drajaysaha@yahoo.in

DOI:10.14260/jemds/2015/2553
This retrospective study includes 719 cases who underwent laparoscopic cholecystectomy during the period February 2012 to January 2015 of which 163 were Tribals and remaining 556 were non-Tribals. History and symptoms of presentation were noted in both the groups and duration to first consultation also noted in both the groups. Pneumoperitoneum was created by Veress needle through sub-umbilical incision in all patients. This was used for introducing the $10 \mathrm{~mm}$ trocar. The pressure of $\mathrm{CO}_{2}$ varied between 12 to $15 \mathrm{mmHg}$. Other port sites were used as in conventional method. Resumption of oral feed, postoperative recovery and postoperative day of discharge were recorded in both the groups.

\section{OBSERVATIONS AND DISCUSSION}

In this study we observed that history including duration of symptoms is 1 year in Tribals whereas 6 months in nonTribals. Duration to first consultation it is late in Tribals, is of 1 year in Tribals whereas 6 months in non-Tribals.

Following points and steps were considered to note the difficulties in performing laparoscopic cholecystectomy in the two aforesaid groups. Easy or straight forward cases were not taken into account. 


\begin{tabular}{|c|c|c|c|}
\hline $\begin{array}{l}\text { Sl. } \\
\text { No. }\end{array}$ & Features & Tribals & $\begin{array}{c}\text { Non- } \\
\text { Tribals }\end{array}$ \\
\hline \multirow[t]{6}{*}{1.} & $\begin{array}{l}\text { Adhesions of Gall } \\
\text { Bladder: }\end{array}$ & & \\
\hline & $\begin{array}{l}\text { a) With Omentum and } \\
\text { adjacent viscera:- }\end{array}$ & 26 & 133 \\
\hline & b) Thick adhesions & 5 & 41 \\
\hline & c) Tough adhesions & 4 & 38 \\
\hline & $\begin{array}{l}\text { d) Inflamed adhesions } \\
\text { with neovascularisation }\end{array}$ & 2 & 23 \\
\hline & $\begin{array}{l}\text { e) Between Liver and } \\
\text { Diaphragm }\end{array}$ & 1 & 14 \\
\hline 2. & Thick Gall Bladder wall & 53 & 241 \\
\hline 3. & $\begin{array}{c}\text { Long Gall Bladder } \\
\text { mesentery }\end{array}$ & 39 & 41 \\
\hline 4. & $\begin{array}{c}\text { Scarring in Calot's } \\
\text { Triangle }\end{array}$ & 2 & 23 \\
\hline 5. & Friability of Gall Bladder & 2 & 22 \\
\hline 6. & $\begin{array}{c}\text { Gangrene of Gall Bladder } \\
\text { in } \\
\text { acute calculous } \\
\text { cholecystitis } \\
\end{array}$ & 0 & 1 \\
\hline 7. & Biliary Enteric Fistula: & 0 & 2 \\
\hline 8. & $\begin{array}{c}\text { Peroperative diagnosis } \\
\text { of diseased liver (e.g. } \\
\text { Cirrhosis) }\end{array}$ & 2 & 5 \\
\hline 9. & $\begin{array}{l}\text { Difficult dissection at the } \\
\text { liver bed }\end{array}$ & 1 & 34 \\
\hline 10. & $\begin{array}{c}\text { Adequate working space } \\
\text { within the abdomen } \\
\text { in patients of varying } \\
\text { body habitus } \\
\end{array}$ & $\begin{array}{c}\text { No } \\
\text { difference }\end{array}$ & $\begin{array}{c}\text { No } \\
\text { difference }\end{array}$ \\
\hline 11. & $\begin{array}{l}\text { Conversion to open } \\
\text { cholecystectomy }\end{array}$ & 2 & 19 \\
\hline 12. & $\begin{array}{c}\text { Total time required for } \\
\text { operation }\end{array}$ & 39 & 46 \\
\hline \multicolumn{4}{|c|}{ Table 1} \\
\hline
\end{tabular}
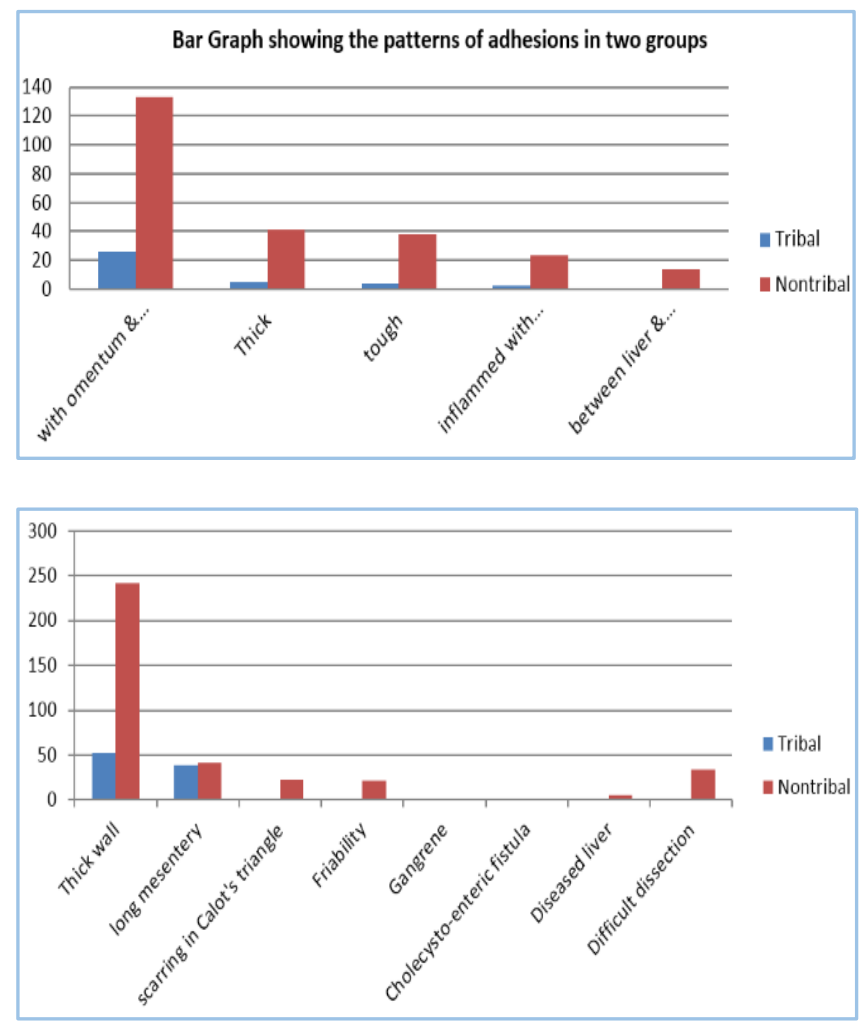

Pathoanatomical variations in two groups

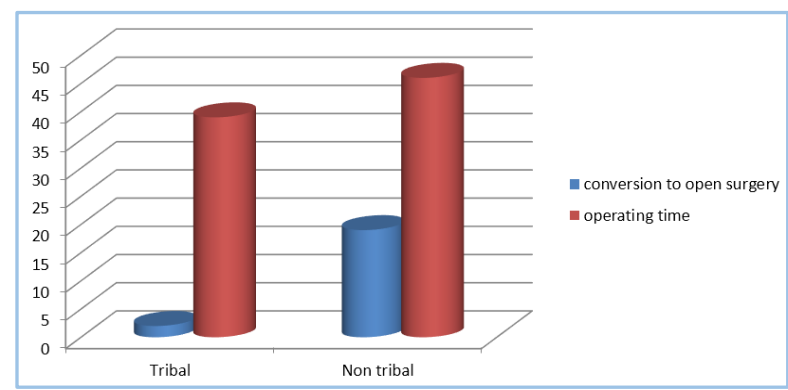

Conversion rate and total time

Calculous biliary tract disease is a major healthcare problem all over the world. Diet plays an important role in formation of Gall stone. Incidence of cholesterol gall stone increases with increased intake of dietary fat. Gall stones are more common in certain families. Current data suggests that $30 \%$ risk of Gall stone is hereditary and $70 \%$ is environmental, diet being the primary environmental factor. ${ }^{3}$ There is high prevalence in Native Americans and this points to the importance of genetic factor in the aetiopathogenesis of Gall stone. ${ }^{4}$

It has been observed that the disease is more prevalent in non-Tribals than Tribals. While performing laparoscopic cholecystectomy, it has been noted that adhesions of Gall Bladder are more common in non-Tribals; $15.95 \%$ of Tribals had adhesions with omentum and adjacent viscera in contrast to $23.9 \%$ in non-Tribals; $19.2 \%$ of adhesions were thick in Tribals whereas $30.82 \%$ were thick in non-Tribals; $15.38 \%$ adhesions were tough in Tribals in comparison to $28.57 \%$ amongst non-Tribals.

Only $7.69 \%$ of adhesions were inflamed with neovascularisation in Tribals in contrast to $17.29 \%$ in nonTribals. Gall Bladder wall is thick in $31.51 \%$ in Tribals, whereas it was $43.34 \%$ in non-Tribals. Scarring of the Calot's triangle was present in $1.22 \%$ in Tribals and $4.15 \%$ in nonTribals. Adhesion between liver and diaphragm was present in $0.61 \%$ of Tribals and $2.51 \%$ non-Tribals. Friability of Gall Bladder $1.22 \%$ in Tribals in contrast to $3.95 \%$ in non-Tribals. Cirrhotic liver $1.22 \%$ in Tribals and $0.89 \%$ in non-Tribals. Gall Bladder bed dissection $0.61 \%$ in Tribals and $6.11 \%$ in nonTribals.

\section{CONCLUSION}

Laparoscopic cholecystectomy is comparatively easier in Tribals than non-Tribals due to difference in pathoanatomy including relatively redundant mesentery of Gall bladder making the dissection easier.

\section{BIBLIOGRAPHY}

1. Thai H Pham, John G Hunter. Schwartz's Principles of Surgery, $10^{\text {th }}$ Edition 2015, New York. Gall bladder and the extrahepatic biliary system; 32:1309-1340.

2. Sanjeev Singla, Sandeep Singla, Sushil Budhiraja. Port site metastasis after laparoscopic cholecystectomy. Indian Journal of Surgery, Jan-Feb 2009;1:71:41-42.

3. Henry A Pitt, Steven A Ahrendt and Attila Nakeeb. Greenfield's Surgery Scientific Principles and Practice, $5^{\text {th }}$ Edition, 2011, Philadelphia. Calculus Biliary Disease. 60:960-980 Lippincott Williams \& Wilkins.

4. Nathanson LK. Hepatobiliary and pancreatic Surgery, $5^{\text {th }}$ Edition 2014. Saunders Elsevier Philadelphia 10:174195. 